\title{
Aggression and Self Esteem Among Teenagers
}

\author{
Beer Singh ${ }^{1}$, Aejaz Hassan ${ }^{2}$ and Mohammad Amin Wani ${ }^{3 *}$ \\ ${ }^{1}$ Head Depart of Psychology \& Dean Faculty of Arts CCS, University Meerut, India \\ ${ }^{2}$ Department of Physical Education and Sports Sciences, Annamalai University, India \\ ${ }^{3}$ Department of Psychology, Annamalai University, India
}

Submission: September 12, 2017; Published: September 27, 2017

*Corresponding author: Mohammad Amin Wani, Research Scholar, Department of Psychology Annamalai University, Tamil Nadu, India, Email: mypsyresearch@outlook.com

\begin{abstract}
The purpose of the present study was to assess the level of aggression and self esteem among teenagers. The study consists 70 participants (Boys 35 and Girls 35) selected randomly from Annamalai University. Aggression Questionnaire (1992) developed by Buss Perry and Rosenberg Self Esteem Questionnaire were used for the assessment. For statistical analysis mean, standard deviation and student's t-test were used. The results revealed that boys are more aggressive than girls; also girls have poor self esteem than boys. Further significant mean difference is found between boys and girls with respect to aggression and self esteem respectively.
\end{abstract}

Keywords: Aggression; Self esteem; Gender; Teen age

\section{Introduction}

Aggression may be defined as the energetic assault on animate or inanimate objects for a purpose. Aggression is always associated with harmful emotional state. The emotion which is called as anger is typically aroused by some provocation [1]. Johnson [2] quoted that aggressive behaviour was associated with destructive acts, sexual attack, prejudice, speech and genital activity. Aggression negatively affects student's academic achievement, and performance, their emotional, mental as well as psychological wellbeing [3]. Wani et al. [4] divulge that boys show high level of aggression than girls. Akhtar \& Kushwaha [5] also confirmed the boys are more aggressive than girls. Talukdar \& Deka [6] also found that the male adolescents are significantly aggressive than female.

Self esteem is defined as individual's positive or negative evaluation of his/ her own personality. Self esteem is self awareness about one's own strength and weakness. It is self acknowledgment, self judgment, individual gratefulness and subjective respect of one's own. Self-esteem is the worthiness judgment related to the self concept [7]. Guindon [8] revealed that self esteem refers to the attitudinal and evaluative component of the self. It involves feelings of worth and acceptance which are developed as a result of the awareness of our competencies and feedback from the world around us. Emerging as common across most definitions of self-esteem is the component of self evaluation. Furnham \& Cheng [9] found self esteem to be both a direct and a moderator variable for young people's self reported happiness. It is also associated with life satisfaction. Parmar [10] confirmed significant gender difference in self esteem. Wani et al. [11] revealed that boys have high level of self esteem than girls. Results also revealed that boys have high self-esteem than girls. Lower self esteem among girls has been attributed to several reasons including less favorable attitudes towards their gender roles and more concerns about appearance although boys seem to be showing increasing amounts of concern as well [12]. Self esteem across the life span Robins et al. [13] found that while self esteem levels were high in childhood, they dropped during adolescence and rose gradually throughout adulthood, once again declining in old age. This trajectory generally held true across gender, socio economic status, ethnicity and nationality. Adolescence therefore emerges as a time of reduction in self esteem.

\section{Objectives}

i. To find the level of aggression among boys and girls.

ii. To find the level of self esteem among boys and girls.

\section{Hypotheses}

i. $\quad$ H1 There would be significant mean difference found between aggression scores of boys and girls.

ii. H2 There would be significant mean difference found between self esteem scores of boys and girls. 


\section{Variables}

i. Independent variable: Gender.

ii. Dependent variables: Aggression and Self Esteem.

\section{Psychological Tools}

Aggression Questionnaire: Aggression Questionnaire by Buss Perry (1992) is 7 point Likert scale with 29 items, including four dimensions namely physical aggression, verbal aggression, hostility, and anger respectively.

Rosenberg Self-Esteem scale: Rosenberg Self Esteem scale (1965) was used for the assessment of self esteem level the scale consists of 10 items with 4 responses. Item 1, 2,4,6,7 are scored as $3,2,1$, and 0 where as item $3,5,8,9,10$ are scored in reversed form.

Results

Table 1; Figure 1

\section{Procedure}

To achieve the purpose of present study a total sample of 70 students $(\mathrm{N}=70)$ between the age group of $15-19$ years were randomly selected from various departments in Annamalai University. The subjects are divided into two equal groups, boys $(n=35)$ and girls $(n=35)$. For the assessment of aggression and self esteem aggression questionnaire developed by Buss Perry (1992) and Rosenberg self esteem questionnaire were used. Before administering the scales proper rapport was established with participants and they were asked about the purpose of the study, after their willingness questionnaires were distributed among them. After 15- 20 minutes participants hand over the filled questionnaires. Therefore data was collected in appropriate manner, after that collected data was analysis through Mean and Standard Deviation, and t-test.

Table 1: Showing mean and standard deviation, standard error mean, mean difference and t- value of participants with respect to aggression and self esteem.

\begin{tabular}{|c|c|c|c|c|c|c|c|c|}
\hline Variable & Category & $\mathbf{N}$ & Mean & S.D & SEM & M.D & df & t-value \\
\hline \multirow[t]{2}{*}{ Aggression } & Boys & 35 & 26.28 & 5.32 & 0.9 & 2.11 & \multirow{2}{*}{68} & \multirow{2}{*}{$2.22^{*}$} \\
\hline & Girls & 35 & 24.17 & 1.82 & 0.3 & & & \\
\hline \multirow[t]{2}{*}{ Self esteem } & Boys & 35 & 14.2 & 2.48 & 0.41 & 1.57 & \multirow{2}{*}{68} & \multirow{2}{*}{$3.45^{* *}$} \\
\hline & Girls & 35 & 12.62 & 1.03 & 0.17 & & & \\
\hline
\end{tabular}

*significant at 0.05 level, **significant at 0.01 level

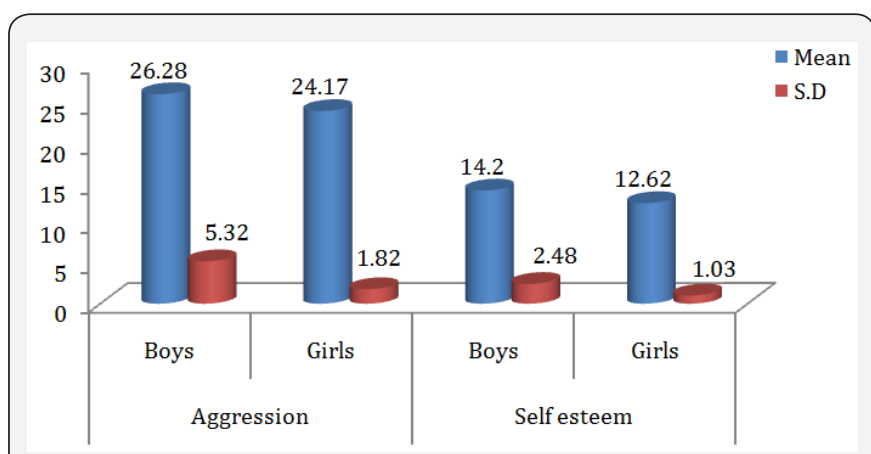

Figure 1: Showing mean and standard deviation, of participants in respect to aggression and self esteem.

\section{Discussion}

The results of present study demonstrated that boys are more aggressive than girls. Simultaneously boys have also high level of self esteem than girls respectively. The Mean, S.D, SEM, and t-value of aggression scores among boys and girls were found [boys, $(M=26.28, S . D=5.32, S E M=0.90)$, girls $(M=24.17$, $\mathrm{S} . \mathrm{D}=1.82$, SEM=0.30)], and $\mathrm{t}$ - value (2.22) were found more than tabulation value at 0.05 level, which reveals that there is significant mean difference between the aggression scores of boys and girls. Therefore the first hypothesis is accepted. These findings are supported by the research by Wani [4], Veiskarami et al. [14], Akhtar \& Kushwaha [15], Talukdar \& Deka [16], Khatri
[17], Bettencourt \& Miller [18], and Malik \& Katyal [19], It is also divulge there is significant mean difference between the self esteem scores of boys and girls, because obtained t- value (3.45) was found significant at 0.01 level. Mean, S.D, SEM, of boys and girls were found [boys, $(\mathrm{M}=14.20, \mathrm{~S} . \mathrm{D}=2.48, \mathrm{SEM}=0.41)$, girls $(M=12.62, S . D=1.03, S E M=0.17)]$ Therefore the second hypothesis is also accepted. Same findings are reported by Wani et al. [11], and Parmar [20] respectively.

\section{Conclusion}

On the basis of the findings of the present study we may conclude boys are more aggressive as all as self esteemed than girls. Also gender is an influential variable in aggression and self esteem respectively.

\section{References}

1. Alderman RB (1974) Psychological behavior in sports. WB Saunders Company, Philadelphia, USA.

2. Johnson R (1972) Aggression in Man and Animals. Saunders, Philadelphia, USA.

3. White JL, Moffitt TE, Earls F, Robins L, Silva PA (1990) How early can we tell? Predictors of childhood conduct disorder and adolescent delinquency. Criminology 28(4): 507-533.

4. Wani MA, Sankar R, Raghavi R, Chinmaya B (2017) Aggression among Annamalai University students. Global Journal of Intellectual \& Developmental Disabilities 1(3): 555562. 
5. Akhtar J, Kushwaha AKS (2015) Gender differences in aggressive behavior of adolescents. Indian Journal of Applied Research 5(1): 525527

6. Talukdar RR, Deka RS (2014) A study on aggression level among adolescents. International Journal of Social Science and Humanities Research 2(4): 91-94.

7. Rosenberg M (1965) Society and the adolescent self image. Princeton University Press, USA.

8. Guindon MH (2002) Toward accountability in the use of the self-esteem construct. Journal of Counseling \& Development 80(2): 204-214.

9. Furnham A, Cheng H (2000) Perceived parental behaviour, self-esteem and happiness. Soc Psychiatry Psychiatr Epidemiol 35(10): 463-470.

10. Parmar SD (2014) Gender and economic status effect on self-esteem among college students. The International Journal of Indian Psychology 2(1): 168-172.

11. Wani MA, Sankar R, Talukdar P, Singha S, Selvarani S (2016) Assertiveness and self esteem among Annamalai university students. International Journal of Psychological Research 5(2): 42-46.

12. Helgeson V (2016) Psychology of gende. Routledge, New York, USA.

13. Robins RW, Trzesniewski KH, Tracy JL, Gosling SD, Potter J (2002) Global self esteem across the life span, Psychology and Aging 17: 423434.
14. Veiskarami HA, Salimy H, Zangiabad M, Hosseini SA (2015) Comparative analysis of physical victimization among male and female high school students of Iran. International Journal of Life Sciences 9 (3): 9-12.

15. Akhtar J, Kushwaha AKS (2015) Gender differences in aggressive behavior of adolescents. Indian Journal of Applied Research 5(1): 525 527.

16. Talukdar RR, Deka RS (2014) A study on aggression level among adolescents. International Journal of Social Science and Humanities Research 2(4): 91-94.

17. Khatri P (2003) Aggression, peer victimization, and social relationships among Indian youth. International Journal of Behavioral Development 27(1): 87-95.

18. Bettencourt BA, Miller N (1996) Gender differences in aggression as a function of provocation: A meta- analysis. Psychol Bull 119: 422-444.

19. Malik A, Katyal S (1993) A comparative study of frustration in daughters of working and non-working mothers. Indian Psychological Review 40 (1,2): 9-13.

20. Parmar SD (2014) Gender and economic status effect on self-esteem among college students. The International Journal of Indian Psychology 2(1): 168-172.

\begin{tabular}{l} 
Your next submission with Juniper Publishers \\
will reach you the below assets \\
- Quality Editorial service \\
- Swift Peer Review \\
- Reprints availability \\
- E-prints Service \\
- Manuscript Podcast for convenient understanding \\
- Global attainment for your research \\
- Manuscript accessibility in different formats \\
( Pdf, E-pub, Full Text, Audio) \\
- Unceasing customer service \\
Track the below URL for one-step submission \\
https://juniperpublishers.com/online-submission.php \\
\hline
\end{tabular}

